\title{
Kombinasi Serat Batang Aren dan Pasir Merapi pada Hidroponik Substrat Kailan
}

\section{Combination of Arenga Wood Fiber and Merapi Sand in Hidroponic Substrate Kailan}

\author{
Anik Fitri Astuti $^{1)}$, Dwi Harjoko ${ }^{2)}$, Muji Rahayu ${ }^{2)}$
}

\begin{abstract}
Kailan is a horticultural commodity that interest but productivity of kailan reduce caused by the cultivation of agricultural land which is getting slightly. Need effort to increase productivity of kailan by applying hydroponic substrate. This study uses merapi sand and arenga wood fiber as a hydroponic substrate medium. Merapi sand is easily porous. Arenga wood fiber is waste produced by palm industry which not used maximum. This study purpose to assess whether the treatment of a mixture of merapi sand and arenga wood fiber with hydroponic substrate systems affect kailan's growth and product. The method used completely randomized design with one factor consists of 1 control and 13 treatments. The results showed that mixture of merapi sand and arenga wood fiber give different effect on variable. Mixture of $25 \%$ arenga wood fiber and $75 \%$ Merapi sand (1: 3 ) have inclined more great value in the roots fresh weight and plant fresh weight. Merapi sand $100 \%$ give inclined more great value in the variable plant height and amount of leaves.
\end{abstract}

Keywords : kailan, hydroponic substrate, arenga wood fiber, Merapi sand

\section{PENDAHULUAN}

Kailan (Brassica alboglabra) merupakan komoditas hortikultura yang diminati masyarakat karena rasanya yang enak serta memiliki kandungan gizi yang dibutuhkan tubuh seperti protein, mineral dan vitamin. Namun menurut data dari BPS (2013) produksi sayur mengalami penurunan dari $287.30 \mathrm{kw} \mathrm{ha}^{-1}$ menjadi $253.70 \mathrm{kw} \mathrm{ha}^{-1}$. Penurunan produksi tersebut juga diikuti dengan terjadinya penurunan luas lahan pertanian dari 5.897 ha menjadi 5.461 ha.

Perlu dilakukan suatu usaha untuk meningkatkan kembali produksi kailan. Usaha untuk meningkatkan produksi kailan dapat dilakukan dengan penerapan sistem budidaya yang baik. Salah satu sistem yang diterapkan adalah hidroponik substrat. Hidroponik substrat adalah sistem hidroponik yang memberikan suatu lingkungan pertumbuhan lebih terkontrol, tidak mengenal musim dan tidak memerlukan lahan yang luas.

Penelitian ini menggunakan pasir merapi dan serat batang aren sebagai media hidroponik substrat. Siswadi dan Teguh Yuwono (2013) menyatakan bahwa media tanam sangat menentukan hasil dalam budidaya hidroponik. Pasir merapi memiliki sifat ringan dan sangat porus serta ukuran butiran relatif kasar. Pasir merapi memiliki kekurangan yaitu poripori berukuran besar (pori makro), mudah basah dan kering oleh proses penguapan sehingga media perlu penyiraman berulang-ulang. Serat batang aren merupakan limbah dari pengolahan tepung aren. Limbah serat batang aren belum di-manfaatkan

\footnotetext{
1) Undergraduate Student of Study Program of Agrotechnology, Faculty of Agriculture, Sebelas Maret University (UNS) on Surakarta

2) Lecturer Staff of Study Program of Agrotechnology, Faculty of Agriculture, Sebelas Maret University (UNS) on Surakarta

Contact Author: anik.fitriastuti@yahoo.com
}

secara maksimal sehingga mempengaruhi ekosistem sekitar, sehingga perlu pemanfaatan limbah serat aren sebagai media hidroponik substrat. Selain itu, serat batang aren memiliki kapasitas menahan air tinggi. Penelitian bertujuan untuk mengkaji apakah perlakuan campuran pasir merapi dan serat aren mempengaruhi pertumbuhan dan hasil kailan. Campuran serat batang aren dan pasir merapi optimal untuk pertumbuhan dan hasil kailan.

\section{METODE PENELITIAN}

Penelitian dilakukan di screen house Fakultas Pertanian Univertitas Sebelas Maret Surakarta dengan ketinggian tempat 95 mdpl pada September 2014 sampai Desember 2014. Bahan yang digunakan meliputi: benih kailan varietas round leaf, serat batang aren, nutrisi AB Mix, air, pasir merapi, dan arang sekam. Alat yang digunakan yaitu mesin penggiling, gelas ukur, klorofil meter, EC meter, bak penanaman, timbangan digital, dan oven.

Penelitian menggunakan Rancangan Acak Lengkap (RAL) dengan satu faktor. Satu faktor tersebut terdiri dari 13 perlakuan dan 1 kontrol arang sekam, masing - masing diulang 4 kali. Tiga belas perlakuan terdiri dari campuran serat batang aren dan pasir merapi. Serat batang aren terdiri dari 3 taraf : panjang 10.45 $1.49 \mathrm{~cm}$, sedang $5.20 \pm 1.20 \mathrm{~cm}$ dan pendek $1.68 \pm 0.69 \mathrm{~cm}$. Campuran serat batang aren dan pasir merapi terdiri dari 5 taraf yaitu serat batang aren $100 \%$, serat batang aren $75 \%$ pasir merapi 25 $\%(3: 1)$, serat batang aren $50 \%$ pasir merapi $50 \%$ $(1: 1)$, serat batang aren $25 \%$ pasir merapi $75 \%(1: 3)$, dan pasir merapi $100 \%$.

Pelaksanaan penelitian meliputi analisis fisik media, persiapan media tanam, persiapan bahan tanaman, penanaman, pemeliharaan, panen. Variabel pengamatan antara lain tinggi tanaman, jumlah daun, kadar klorofil, luas daun, panjang akar, volume akar, berat segar akar, berat segar tanaman dan rasio akar 
tajuk. Pengamatan dilakukan setiap seminggu sekali dan setelah panen. Data dianalisis menggunakan analisis ragam (Anova) dengan uji $F 5 \%$ dan apabila terdapat beda nyata dilanjutkan uji jarak berganda (DMRT) taraf $5 \%$.

\section{HASIL DAN PEMBAHASAN}

Penelitian dilakukan di Screen House Fakultas Pertanian Univertitas Sebelas Maret Surakarta dengan ketinggian tempat 95 mdpl pada September 2014 sampai Desember 2014. Di dalam screen house terdapat selada, tomat, cabai keriting dan cabai rawit. Tanama di sekitar tempat penelitian tidak mempengaruhi pertumbuhan dan hasil tanaman kailan. Hama pada tanaman kailan adalah ulat daun dengan gejala daun bagian bawah berlubang. Pengendalian hama ulat daun dilakukan secara mekanis. Suhu screen house:

pukul 07.00-09.00 adalah $27^{\circ} \mathrm{C}$ kelembapan $88 \%$, pukul 11.00-13.00 adalah $32^{\circ} \mathrm{C}$ kelembapan $85 \%$, pukul 14.00-16.00 adalah $31^{\circ} \mathrm{C}$ kelembapan $78 \%$.

Pertumbuhan tanaman merupakan hasil dari berbagai proses fisiologi, melibatkan faktor genotipe yang berinteraksi dalam tubuh tanaman dengan faktor lingkungan. Proses tersebut yaitu pertambahan ukuran dan jumlah. Ciri-ciri pertumbuhan pada tanaman yang tampak sebagai fenotipe utamanya dipengaruhi oleh faktor genotipe, sedangkan ciri-ciri lainnya ditentukan oleh pengaruh lingkungan sehingga pertumbuhan merupakan pengaruh dari genotipe dan lingkungan. Faktor lingkungan yang berpengaruh adalah media tumbuh tanaman. Media tumbuh yang baik untuk budidaya tanaman adalah media yang menunjang pertumbuhan dan perkembangan akar serta mencukupi kebutuhan tanaman akan nutrisi. Manipulasi media tumbuh yang tepat adalah dengan membuat komposisi media yang mempertahankan kelembaban tanah dalam waktu relatif lebih lama.

\section{Tinggi Tanaman}

Salah satu variabel untuk mengetahui pertumbuhan tanaman adalah tinggi tanaman. Pertambahan ukuran yang terjadi pada tinggi tanaman menunjukkan bahwa terjadi suatu proses yang timbul sebagai akibat terjadinya pembesaran sel kearah titik tumbuh. Faktor yang mempengaruhi pertumbuhan tidak hanya genetik, tetapi juga disebabkan oleh unsur lingkungan salah satunya adalah media tanam (Marliah 2010).

Berdasarkan gambar 1 pasir merapi 100\% menunjukkan hasil paling baik yaitu $8,83 \mathrm{~cm}$ diikuti campuran serat sedang dengan pasir merapi (1:1) sebesar $8,71 \mathrm{~cm}$. Media arang sekam sebagai kontrol (pembanding) memberikan hasil tidak berbeda nyata dengan campuran serat sedang dengan pasir merapi (1:1). Hal Ini menujukkan bahwa pada komposisi pasir $100 \%$ dan campuran serat sedang pasir merapi (1:1) memberikan pertumbuhan tanaman yang baik, karena meningkatkan tinggi tanaman kailan. Hal ini karena sifat pasir yang memiliki kapasitas menahan air rendah. Sebagian besar tersusun dari pori-pori besar yang sangat efisien untuk pergerakan air dan udara sehingga aerasi baik (Foth 1994). Sifat pasir yang rendah kapasitas menahan airnya sesuai dengan tanaman kailan yang dalam pertumbuhannya tidak memerlukan banyak air.

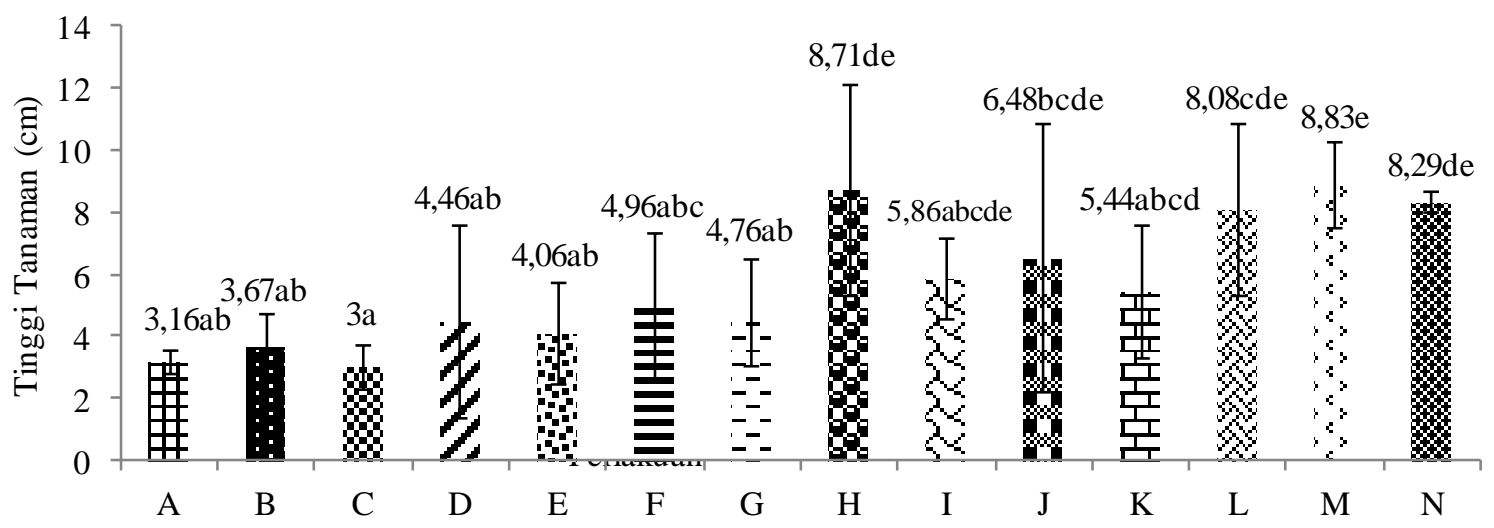
Keterangan:
- Angka yang diikuti huruf sama menunjukkan tidak berbeda nyata pada uji DMRT taraf $5 \%$.
A : serat panjang
$\mathrm{H}$ : serat sedang :pasir merapi $(1: 1)$
$B$ : serat sedang
$\mathrm{I}$ : serat pendek : pasir merapi $(1: 1)$
C : serat pendek
$\mathrm{J}$ : serat panjang : pasir merapi $(1: 3)$
D : serat panjang : pasir merapi (3:1)
$\mathrm{K}$ : serat sedang : pasir merapi $(1: 3)$
E : serat sedang : pasir merapi $(3: 1)$
$F$ : serat pendek : pasir merapi $(3: 1)$
$\mathrm{L}$ : serat pendek : pasir merapi $(1: 3)$
$M$ : pasir merapi
$\mathrm{G}$ : serat panjang : pasir merapi $(1: 1)$
$\mathrm{N}$ : arang sekam

Gambar 1. Pengaruh perlakuan terhadap tinggi tanaman kailan 
Campuran serat sedang dan pasir merapi (1:1) juga menghasilkan pertumbuhan baik karena serat aren merupakan bahan organik. Menurut Syukur (2008) fungsi bahan organik adalah memperbaiki struktur tanah dan daya simpan air. Penambahan bahan organik pada tanah kasar (berpasir), akan meningkatkan pori yang berukuran menengah dan meningkatkan kemampuan menahan air.

Serat batang aren 100\% untuk semua ukuran menunjukkan hasil paling rendah diantara semua perlakuan. Hal ini karena serat batang aren merupakan media yang memiliki kapasitas menahan air tinggi. Genangan yang semakin lama mengakibatkan cekaman aerasi sehingga tanaman tidak dapat tumbuh optimal.

\section{Jumlah Daun}

Gambar 2 menunjukkan hasil bahwa pasir merapi $100 \%$ memberikan hasil paling baik yaitu 6,22 diikuti campuran serat pendek dan pasir merapi (1:3) sebesar 6,01 dan campuran serat sedang pasir merapi (1:1) sebesar 5,95. Media arang sekam sebagai kontrol (pembanding) memberikan hasil tidak berbeda nyata dari perlakuan tersebut. Ini menujukkan bahwa pada komposisi pasir 100\%, campuran serat pendek dengan pasir merapi (1:3) dan campuran serat sedang pasir merapi (1:1) memberikan pertumbuhan tanaman yang baik, karena meningkatkan jumlah daun kailan. Hal ini karena sifat pasir dengan fraksi pasir lebih besar mengakibatkan aerasi lebih baik. Aerasi yang baik dan pemberian nutrisi yang maksimal akan meningkatkan penyerapan nutrisi oleh akar sehingga pertumbuhan tanaman maksimal.

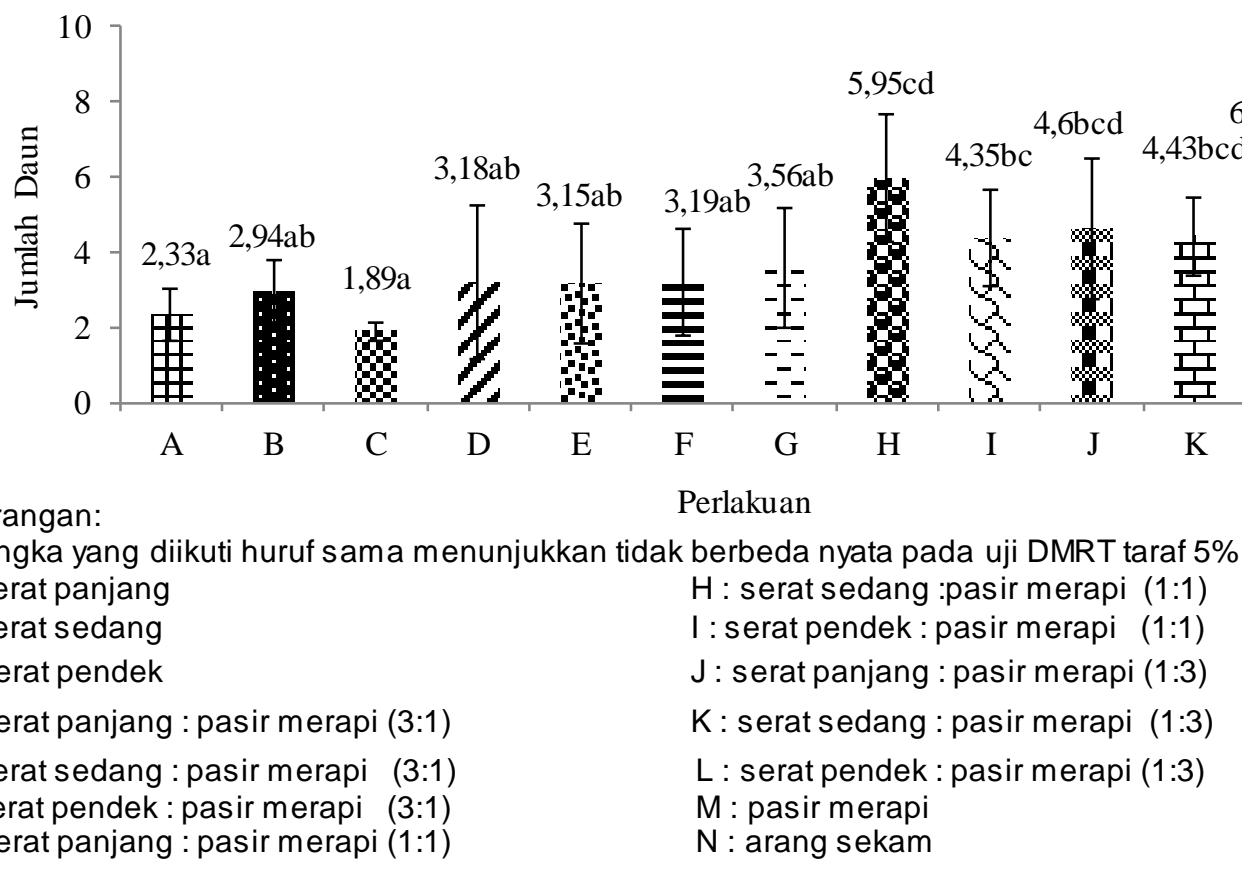

Keterangan:

- Angka yang diikuti huruf sama menunjukkan tidak berbeda nyata pada uji DMRT taraf $5 \%$.
A : serat panjang
$\mathrm{H}$ : serat sedang :pasir merapi $(1: 1)$
B : serat sedang
$\mathrm{J}$ : serat panjang : pasir merapi $(1: 3)$
$D$ : serat panjang : pasir merapi (3:1)
$\mathrm{K}$ : serat sedang : pasir merapi $(1: 3)$
E : serat sedang : pasir merapi $(3: 1)$
$\mathrm{F}$ : serat pendek : pasir merapi $(3: 1)$
$M$ : pasir merap

Gambar 2. Pengaruh perlakuan terhadap jumlah daun

Penambahan pasir merapi pada serat batang aren (1:3) memperbaiki sifat fisik serat aren. Serat aren yang memiliki kemampuan menahan air tinggi hingga menggenang di-perbaiki oleh sifat pasir merapi yang mudah menguapkan air. Sehingga kelebihan air pada media dapat dikurangi. Semakin banyak pasir yang ditambahkan semakin besar pula jumlah daun yang dihasilkan karena sifat dari pasir sebagai media yang sesuai untuk kailan. Hal ini dapat dilihat juga pada perlakuan semua ukuran serat 100\% memberikan hasil rendah. Hal ini karena serat batang aren memiliki sifat mudah menggenang. Sifat tersebut mengakitabkan banyaknya jamur yang tumbuh.

Nutrisi hidroponik utamanya nitrogen yang maksimal diserap mempengaruhi jumlah daun dan jumlah daun mempengaruhi luas daun dan bobot segar tajuk. Seperti yang dikatakan oleh (Riry et al. 2013) nitrogen berfungsi dalam merangsang pertumbuhan tanaman secara keseluruhan, yang merupakan bagian dari sel tanaman itu sendiri dan dapat merangsang pertumbuhan vegetatif tanaman. Jika semakin banyak nitrogen yang terserap tanaman, maka semakin banyak pula jumlah daun yang terbentuk.

\section{Kadar Klorofil}

Besarnya klorofil dapat mempengaruhi pertumbuhan dan hasil kailan. Semakin tinggi klorofil maka proses fotosintesis akan semakin besar sehingga fotosintat yang dihasilkan semakin tinggi. Gambar 3 menunjukkan hasil bahwa pasir merapi $100 \%$ memberikan hasil paling baik yaitu 51,48 diikuti campuran serat pendek dan pasir merapi (1:3) sebesar 46.4 dan campuran serat sedang pasir merapi (1:1) sebesar 46,38. Media arang sekam sebagai kontrol (pembanding) memberikan hasil tidak berbeda nyata dari perlakuan pasir merapi $100 \%$. Hal 


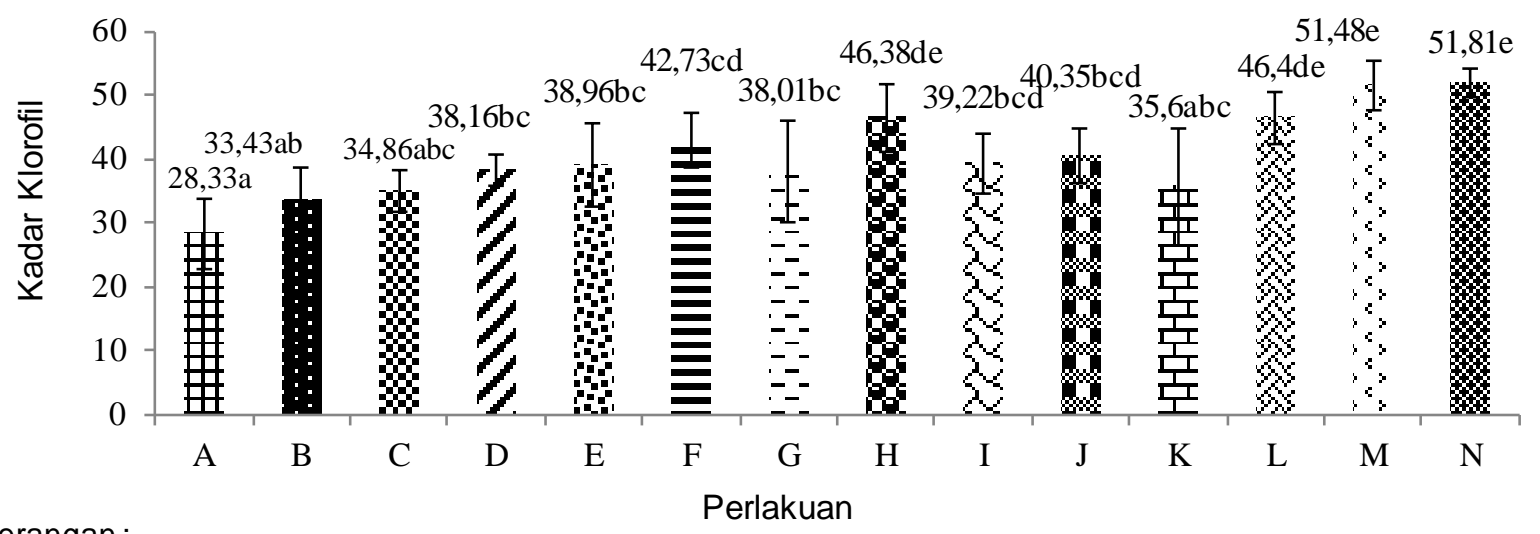

Keterangan :

- Angka yang diikuti huruf sama menunjukkan tidak berbeda nyata pada uji DMRT taraf $5 \%$

A : serat panjang

$B$ : serat sedang

$H$ : serat sedang :pasir merapi $(1: 1)$

C : serat pendek

I : serat pendek: pasir merapi $(1: 1)$

$\mathrm{J}$ : serat panjang : pasir merapi $(1: 3)$

D : serat panjang : pasir merapi (3:1)

$\mathrm{K}$ : serat sedang : pasir merapi $(1: 3)$

E : serat sedang : pasir merapi $(3: 1)$

$F$ : serat pendek : pasir merapi $(3: 1)$

$G$ : serat panjang : pasir merapi (1:1)

$L$ : serat pendek : pasir merapi $(1: 3)$

$M$ : pasir merapi

$\mathrm{N}$ : arang sekam

Gambar 3. Pengaruh perlakuan terhadap kadar klorofil

ini menujukkan bahwa perlakuan tersebut mampu meningkatkan kadar klorofil daun kailan.

Tingginya kadar klorofil disebabkan oleh media yang digunakan. Pasir merapi memiliki aerasi yang baik dan dengan pemberian nutrisi secara rutin mencegah keringnya media pasir akibat penguapan air. Hal ini mengakibatkan aerasi dan drainasi media pasir merapi baik. Campuran serat pendek dan pasir merapi (1:3) memiliki hasil yang tidak berbeda nyata. Hal ini karena sifat fisik dalam kemampuan menahan air dari kedua media tersebut saling melengkapi. Serat aren yang mampu menahan air dan pasir merapi yang memiliki aerasi baik. Dengan media yang mendukung tersebut makan kailan dapat tumbuh dan berkembang maksimal. Kailan tumbuh lebih besar dengan daun yang lebih lebar dan hijau. Daun yang lebar dan hijau menandakan bahwa kadar klorofil tinggi, dan kadar klorofil yang tinggi meningkatkan pertumbuhan dan hasil kailan karena meningkatkan proses fotosintesis.

Kadar klorofil dipengaruhi oleh pigmen daun, semakin hijau warna daun, semakin tingga kadar klorofilnya. Salisbury (1995) menyatakan jumlah klorofil tidak hanya dipengaruhi oleh jumlah pigmen saja, namun luas permukaan daun. Semakin luas daun, semakin luas daerah pencahayaan dan banyaknya jaringan palisade dan jaringan sponsa yang terdapat pada daun.

\section{Panjang Akar}

Gambar 4 menunjukkan hasil bahwa pasir merapi $100 \%$ memberikan hasil paling baik yaitu 18,24 cm diikuti campuran serat pendek dan pasir merapi (1:3) sebesar 15,06 cm Media arang sekam sebagai kontrol (pembanding) memberikan hasil paling besar yaitu 25,36 cm. Ini menujukkan bahwa perlakuan belum mampu meningkatkan panjang akar kailan. Arang sekam memiliki sifat porositas baik, steril, mudah mengikat air, tidak mudah lapuk dan tidak mudah menggumpal sehingga mudah ditembus akar tanaman yang mengakibatkan panjang akar optimal. Pertumbuhan akar sangat di-pengaruhi oleh keadaan fisik tanahnya. Struktur tanah yang padat akan menghambat laju penetrasi akar lebih dalam. Karena tanah padat susah ditembus akar, maka daerah pemanjangan akar semakin pendek. Hal ini sesuai dengan pernyataan Rusdiana (2000), tanah yang memiliki tingkat kepadatan tinggi total panjang akarnya rendah.

\section{Berat Segar Akar}

Gambar 5 menunjukkan hasil bahwa campuran serat pendek dan pasir merapi (1:3) memberikan hasil paling baik yaitu $3,77 \mathrm{~g}$ dimana perlakuan ini tidak berbeda nyata dengan pasir merapi $100 \%$ sebesar 3,62 g dan arang sekam sebagai kontrol (pembanding). Hal Ini menujukkan bahwa perlakuan mampu meningkatkan berat segar akar. Hal ini karena penambahan bahan organik yaitu serat batang aren mampu memperbaiki sifat fisika pasir merapi. Bahan organik dapat diharapkan merubah struktur tanah dari berbutir tunggal menjadi bentuk gumpal, sehingga memperbaiki derajat struktur dan ukuran agregat. Perbaikan sifat fisik mengakibatkan kemampuan menahan air tinggi. Kemampuan menahan air pasir merapi 18,53 diperbaiki dengan penambahan serat batang aren pendek dengan kemampuan menahan air 123,335. Keadaan tersebut membuat akar tanaman berkembang dan menyerap nutrisi dengan maksimal.

Menurut Musnamar (2003) pembentukan akar dipengaruhi oleh persedian hara pada media tanam dan porositas media yang semakin baik dranase dan aerasenya akan semakin baik perkembangan akar sehingga pembentukan sel-sel tumbuh lebih baik. 
Serapan nutrisi yang meningkat me-nyebabkan kebutuhan unsur hara pada fase vegetatif tanaman tercukupi, sehingga mampu meningkatkan bobot segar akar tanaman. Berat segar akar mengindikasikan kemampuan suatu tanaman untuk menyerap air, karena tanaman yang memiliki berat segar akar yang tinggi memiliki perakaran yang lebih besar serta memiliki tingkat toleransi lebih tinggi terhadap kekeringan dibandingkan dengan tanaman dengan berat segar akar yang rendah (Kurniasih dan Wulandhany 2009).

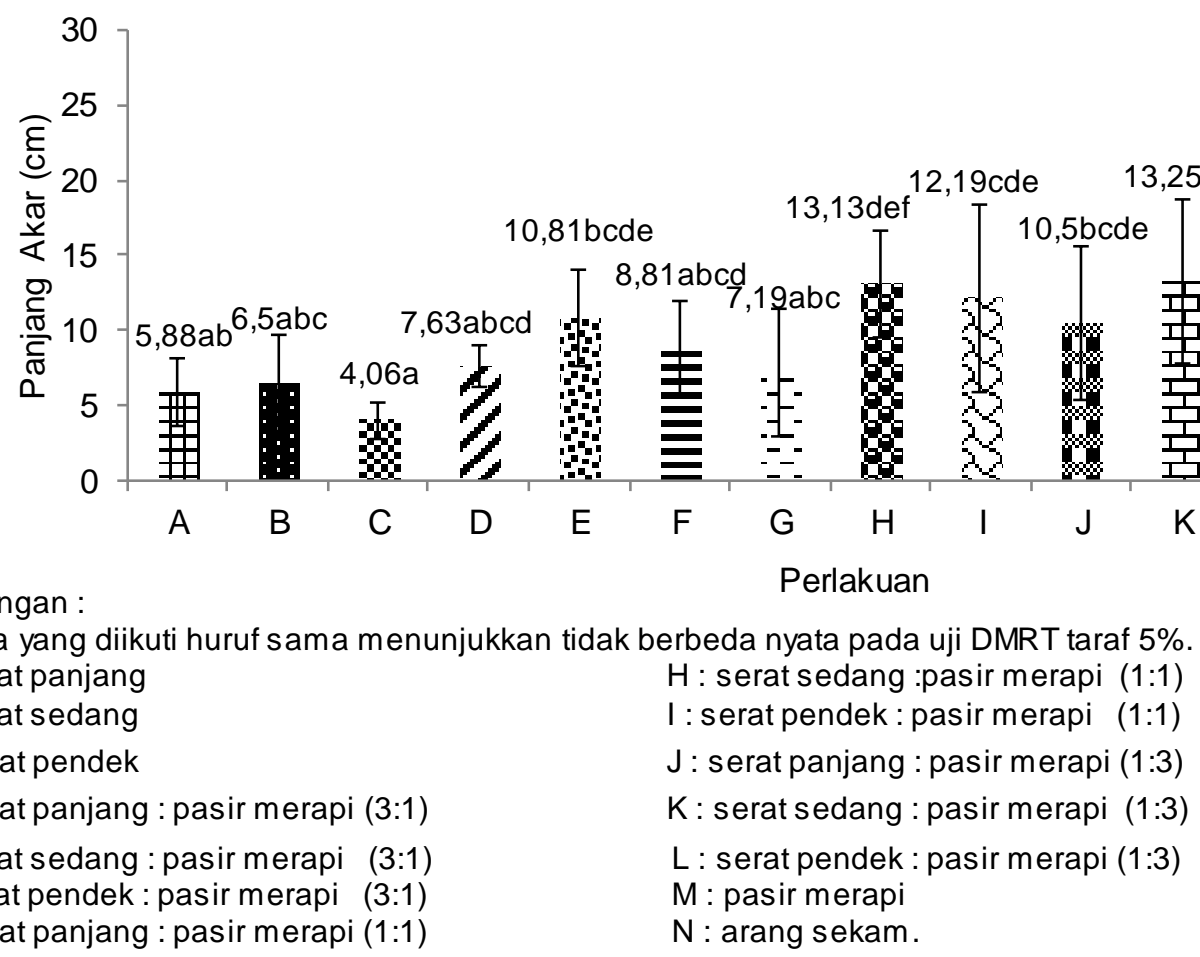

Keterangan :

- Angka yang diikuti huruf sama menunjukkan tidak berbeda nyata pada uji DMRT taraf $5 \%$.
A : serat panjang
$B$ : serat sedang
$\mathrm{J}$ : serat panjang : pasir merapi $(1: 3)$
C : serat pendek
$\mathrm{K}$ : serat sedang : pasir merapi (1:3)
D : serat panjang : pasir merapi $(3: 1)$
$L$ : serat pendek : pasir merapi $(1: 3)$
$\mathrm{F}$ : serat pendek : pasir merapi $(3: 1)$
$\mathrm{G}$ : serat panjang : pasir merapi $(1: 1)$
$\mathrm{N}$ : pasir merapi

Gambar 4. Pengaruh perlakuan terhadap panjang akar

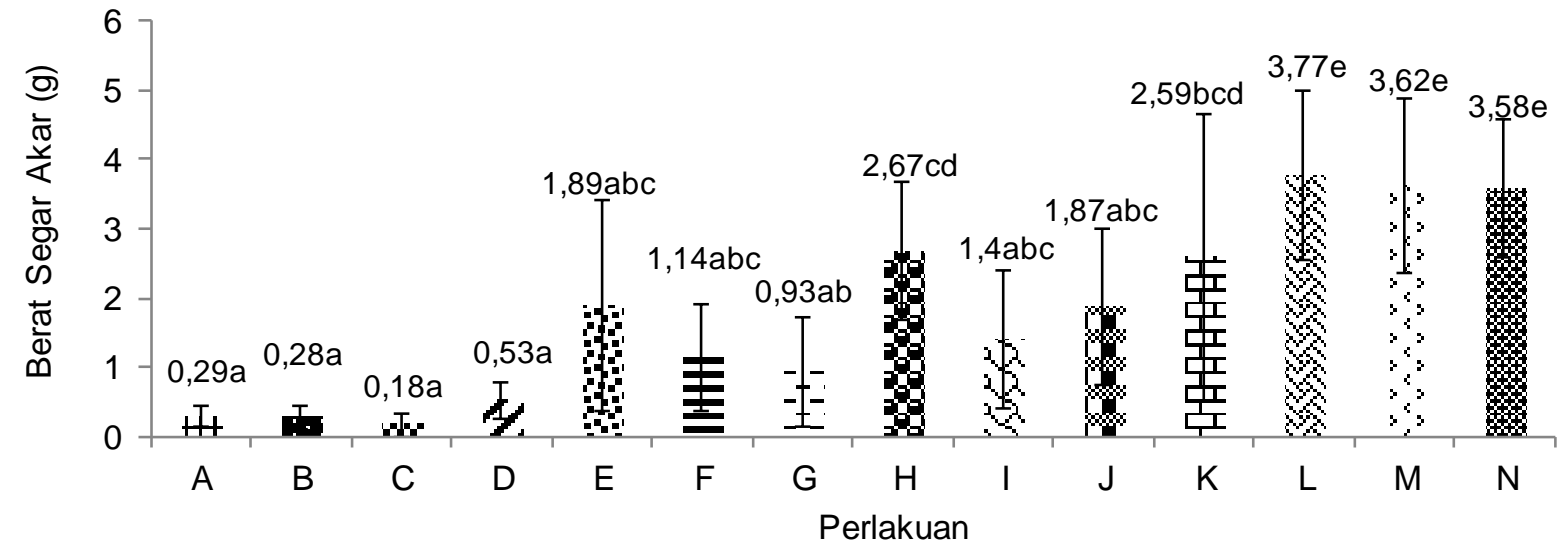

Keterangan :

- Angka yang diikuti huruf sama menunjukkan tidak berbeda nyata pada uji DMRT taraf $5 \%$.
A : serat panjang
$B$ : serat sedang
C : serat pendek
D : serat panjang : pasir merapi $(3: 1)$
E : serat sedang : pasir merapi (3:1)
$\mathrm{F}$ : serat pendek : pasir merapi $(3: 1)$
G : serat panjang : pasir merapi $(1: 1)$

$\mathrm{H}$ : serat sedang :pasir merapi $(1: 1)$

I: serat pendek : pasir merapi $(1: 1)$

$\mathrm{J}$ : serat panjang : pasir merapi $(1: 3)$

$\mathrm{K}$ : serat sedang : pasir merapi $(1: 3)$

$\mathrm{L}$ : serat pendek : pasir merapi $(1: 3)$

$M$ : pasir merapi

$\mathrm{N}$ : arang sekam.

Gambar 5. Pengaruh perlakuan terhadap berat segar akar 


\section{Berat Segar Tanaman}

Gambar 6 menunjukkan hasil bahwa campuran serat pendek dan pasir merapi (1:3) memberikan hasil paling baik yaitu $67,32 \mathrm{~g}$ dan tidak beda nyata dengan pasir merapi $100 \%$ sebesar $66,05 \mathrm{~g}$. Arang sekam sebagai kontrol memberikan hasil lebih rendah yaitu 56,91. Hal Ini menujukkan bahwa perlakuan mampu meningkatkan berat segar tanaman.

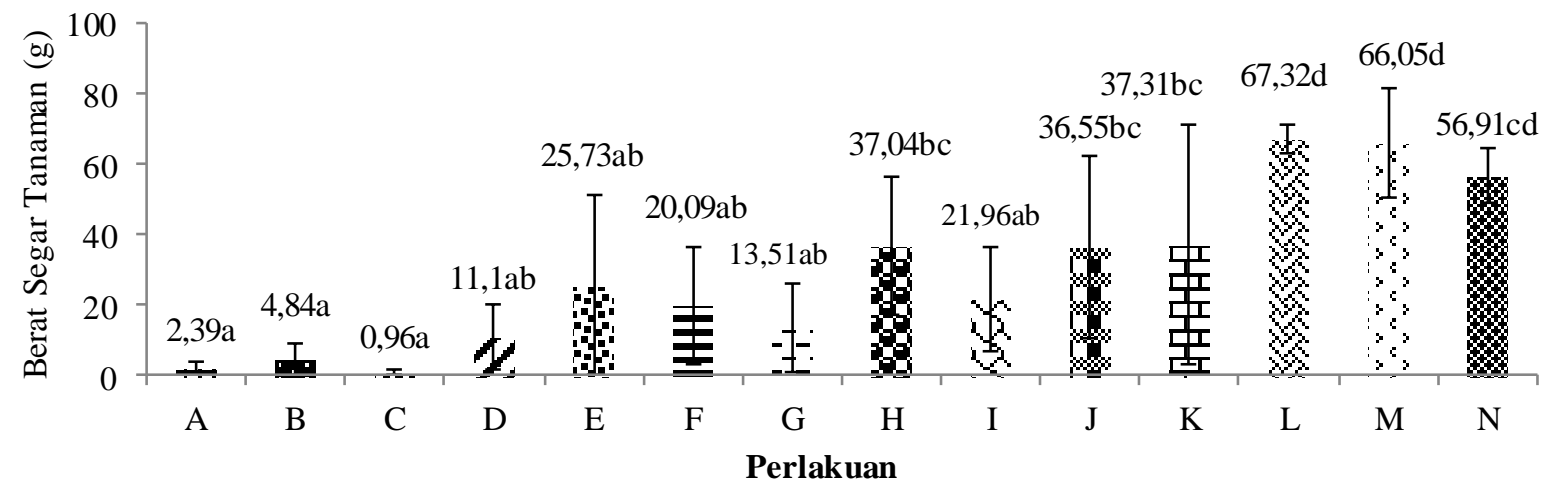

Keterangan :

- Angka yang diikuti huruf sama menunjukkan tidak berbeda nyata pada uji DMRT taraf $5 \%$.

A : serat panjang

$\mathrm{H}$ : serat sedang :pasir merapi $(1: 1)$

$B$ : serat sedang

I : serat pendek: pasir merapi $(1: 1)$

C : serat pendek

$\mathrm{J}$ : serat panjang : pasir merapi $(1: 3)$

D : serat panjang : pasir merapi (3:1)

E : serat sedang : pasir merapi $(3: 1)$

$F$ : serat pendek : pasir merapi $(3: 1)$

$\mathrm{G}$ : serat panjang : pasir merapi (1:1)

$\mathrm{K}$ : serat sedang : pasir merapi $(1: 3)$

$L$ : serat pendek : pasir merapi $(1: 3)$

$M$ : pasir merapi

$\mathrm{N}$ : arang sekam

Gambar 6. Pengaruh perlakuan terhadap berat segar tanaman

Salisbury (1995) serta Sitompul dan Guritno (1995) menyatakan bahwa berat segar tanaman dapat menunjukkan aktivitas metabolisme tanaman dan nilai berat segar tanaman dipengaruhi oleh kandungan air jaringan, unsur hara dan hasil metabolisme. Berat segar sangat dipengaruhi oleh kondisi kelembaban media. Berat segar tanaman kailan perlakuan campuran serat pendek dan pasir merapi (1:3) pasir merapi $100 \%$ menunjukkan hasil yang tinggi. Jadi dapat dikatakan bahwa pada tanaman tersebut kandungan air dan komposisi jaringan tanaman tinggi. Hal ini karena kemampuan menahan air dari media campuran serat pendek dan pasir merapi (1:3) sangat tinggi sehingga ketersediaan air sangat tercukupi.

Kebutuhan air yang terpenuhi dapat meningkatkan berat segar tanaman. Semakin baik hara terserap, maka ketersediaan bahan dasar fotosintesis akan semakin baik. Proses fotosintesis yang baik dapat mengakumulasi karbohidrat secara optimal yang akan berpengaruh terhadap berat segar tanaman.

Perlakuan serat batang aren $100 \%$ menunjukkan hasil berat segar tanaman rendah. Hal ini karena akar kailan yang terendam lama dan membusuk mengakibatkan pengangkutan nutrisi ter-hambat. Translokasi nutrisi yang terhambat mengakibatkan penurunan berat segar tanaman.

\section{KESIMPULAN DAN SARAN}

Berdasarkan hasil penelitian maka dapat diambil beberapa kesimpulan, campuran serat batang aren dan pasir merapi memberi hasil berbeda pada variabel tinggi tanaman, jumlah daun, kadar klorofil, luas daun, panjang akar, volume akar, berat segar akar dan berat segar tanaman. Perlakuan yang memberi hasil rerata tertinggi adalah pasir $100 \%$ dan campuran serat aren pendek dan pasir merapi (1:3). Pasir merapi $100 \%$ memberi hasil rerata cenderung lebih besar pada variabel tinggi tanaman dan jumlah daun. Campuran serat batang aren pendek dan pasir merapi 1:3 memberi hasil rerata cenderung lebih besar pada variabel berat segar akar dan berat segar tanaman. Campuran serat batang aren 100\% untuk semua ukuran memberi hasil rerata paling rendah pada semua variabel. Saran yang dapat diberikan adalah dengan mengatur pemberian nutrisi agar tidak menggenang. Pengaturan dilakukan dengan pemberian nutrisi pada pagi hari dan membuang kelebihan nutrisi jika terjadi genangan. Merendam serat batang aren sebelum digunakan dengan fungisida dan bakterisida selama semalam untuk mencegah tumbuhnya jamur.

\section{DAFTAR PUSTAKA}

BPS [Badan Pusat Statistik]. 2013. Produksi sayuran di Indonesia. Jakarta (ID): Badan Pusat Statistik Indonesia. http://bps.go.id/. Diakses 2 Februari 2015.

Foth. 1994. Dasar-dasar ilmu tanah. Jakarta (ID): Erlangga.

Kurniasih B, Wulandhany F. 2009. Penggulungan daun, pertumbuhan tajuk dan akar beberapa 
varietas padi gogo pada kondisi cekaman air yang berbeda. Agriv 31: 118-128.

Marliah Ainun. 2010. Pengaruh jarak tanam antar barisan pada sistem tumpang sari beberapa varietas jagung manis dengan kacang merah terhadap pertumbuhan dan hasil. Agrista 14(1): 30-38.

Musnamar. 2003. Pupuk organik. Jakarta (ID): Penebar Swadaya.

Riry N, Rehatta H, Tanasale VL. 2013. Pengaruh berbagai komposisi bokashi ampas biji kakao dan pemberian EM4 berbeda terhadap pertumbuhan dan produksi petsai. J Ilmu Budidaya Tanaman. 2(2): 132-142.

Rusdiana Omo. 2000. Respon pertumbuhan akar tanaman sengon (Paraserianthes falcataria) terhadap kepadatan dan kandungan air tanah podsolik merah kuning. J Man Hutan Trop 6(2): 4353.

Salisbury FB, Ross CW. 1995. Fisiologi tumbuhan. Terjemahan Diah R, Lukman, Sumaryono. Bandung (ID): ITB Press.

Siswadi, Teguh Y. 2013. Uji hasil tanaman sawi pada berbagai media tanam secara hidroponik. J Innofarm 2(1): 44-50.

Sitompul SM, Guritno B. 1995. Analisis pertumbuhan tanaman. Yogyakarta (ID): Gadjah Mada University Press.

Syukur A. 2008. Pengaruh pemberian bahan organik terhadap sifat-sifat tanah dan pertumbuhan caisim di tanah pasir Pantai. J Ilmu Tanah Lingkungan. 5(1): 30-38. 